\title{
Observations on the agonistic behaviour of Lepadogaster lepadogaster purpurea (Pisces: Gobiesocidae)
}

\author{
E. J. Gonçalves, V. C. Almada, S. P. Almeida, D. M. Gonçalves, \\ M. REPAS AND N. SimÕES \\ Unidade de Investigação em Eco-Etologia, Instituto Superior de Psicologia Aplicada, \\ R. Jardim do Tabaco 44, P-1100 Lisboa, Portugal
}

(Received 28 July 1995, Accepted 8 December 1995)

\begin{abstract}
Agonistic behaviour of captive Lepadogaster lepadogaster purpurea was described, forming the first record of such behaviour in the family Gobiesocidae. Both male and female engaged in similar behaviours. The agonistic interactions were related mainly to the control of shelter sites and larger fish tended to chase away and take over the shelter of smaller fish.
\end{abstract}

(C) 1996 The Fisheries Society of the British Isles

Key words: agonistic behaviour; Lepadogaster lepadogaster purpurea; clingfish.

Clingfishes are widely distributed on rocky coasts (Briggs, 1986, 1990), but knowledge of their social behaviour is extremely scarce. This is probably because most species are very small and cryptic and occupy microhabitats, such as among algae (Diplecogaster spp., Eckloiaichthys spp.: Breder \& Rosen, 1966), under boulders (Lepadogaster spp., Chorisochismus spp.: Breder \& Rosen, 1966), inside cavities (Lepadogaster spp.: personal observations), and even among the spines of sea urchins (Diplecogaster spp.: Patzner et al., 1992) and associated with crinoids (Lepadichthys spp.: Fishelson, 1966). Available data refer mainly to the spawning habitat, descriptions of egg masses, parental care and sexual dimorphism (Breder \& Rosen, 1966; Gibson, 1969, 1982; Thresher, 1984). As far as we know, no descriptions of agonistic behaviour are available for the family.

Lepadogaster lepadogaster purpurea (Bonnaterre) is a common clingfish in the intertidal zone of the Eastern Atlantic and the Mediterranean (Briggs, 1986, 1990). In this paper, the agonistic behaviour of $L$. l. purpurea in captivity is described.

Fish were collected in December 1992 (group 1), March 1993 (group 2), August 1994 (group 3) and October 1994 (group 4) under boulders during low tide with a hand net at Arrábida, on the Atlantic coast of Portugal $\left(38^{\circ} 28^{\prime} \mathrm{N}, 8^{\circ} 59^{\prime} \mathrm{W}\right)$, and kept in $63 \times 32 \times 31 \mathrm{~cm}$ and $80 \times 40 \times 38 \mathrm{~cm}$ aquaria with gravel and boulders to provide shelter. Natural photoperiod was maintained by a fluorescent light $(15 \mathrm{~W})$, and temperature varied from $14-17 \cdot 5^{\circ} \mathrm{C}$ (group 1), $18-24^{\circ} \mathrm{C}$ (group 2) and $21-24^{\circ} \mathrm{C}$ (groups 3 and 4). They were fed with shrimp (Palaemon spp.), common cockles (Cerastoderma spp.), and other live marine invertebrates. A total of 24 fishes (total length: males: mean $6.95 \mathrm{~cm}$, S.D. $0 \cdot 48$, range $6.3-7.8 \mathrm{~cm}, n=12$; females: mean $5.45 \mathrm{~cm}$, S.D. 0.69 , range $4.5-6.8 \mathrm{~cm}$, $n=12$ ) was observed for $190 \mathrm{~h}$, including $110 \mathrm{~h}$ of focal and scanning sampling (sensu Martin \& Bateson, 1993). Each group was composed of three males and three females. Males were larger and more colourful than females with reddish unpaired fins and more conspicuous blue eye spots. Details of behaviour patterns were based on frame-by-frame and slow motion analysis of videotape recordings. Statistical analysis was performed using the PC computer program Statgraphics (version 4.0) and the simulation statistical program ACTUS (Estabrook \& Estabrook, 1989) designed for the analysis of contingency tables. This program uses random numbers to simulate 1000 tables, each with the same row and column total of the original table. Each simulated table is compared with the original data table and values smaller than 50 are considered to be

Tel.: +351.1.8863184; fax: +351.1.8860954; email: emanuel@do.ispa.mailpac.pt 
TABLE I(a). Outcomes of agonistic interactions between resident and intruder fish of contrasting body sizes

\begin{tabular}{|c|c|c|}
\hline & Larger resident & Larger intruder \\
\hline Wins outcome & 42 & 19 \\
\hline Loses outcome & 3 & 13 \\
\hline \multicolumn{3}{|c|}{ TABLE I(b). Statistical analysis using ACTUS } \\
\hline & Larger resident & Larger intruder \\
\hline \multicolumn{3}{|l|}{ (i) } \\
\hline Wins outcome & 942 & 86 \\
\hline $\begin{array}{l}\text { Loses outcome } \\
\text { (ii) }\end{array}$ & $19 *$ & 995 \\
\hline Wins outcome & 96 & 950 \\
\hline Loses outcome & 994 & $12 *$ \\
\hline
\end{tabular}

(i) Cases in which simulated values did not exceed observed values; (ii) cases in which observed values did not exceed simulated values. $\chi^{2}=13 \cdot 10$, d.f. $=1$, $P<0 \cdot 001$. For details of ACTUS see Estabrook \& Estabrook (1989).

$* P<0 \cdot 05$ (one tailed).

one-tailed significant $(P<0 \cdot 05)$. The significance of $\chi^{2}$ is assessed by the number of times out of 1000 that the value of $\chi^{2}$ for the simulated tables is equal to or greater than that for the original table (Estabrook \& Estabrook, 1989).

Fishes spent most of their time resting upside-down and attached by their sucker to the underside of boulders. However, when two individuals met, the first stage of agonistic interaction involved the fish turning its head towards the opponent and erecting all its unpaired fins. When they got closer, assuming a parallel or anti-parallel position, this display sometimes changed to a rhythmic undulation of the body in which the fully erected unpaired fins were presented to the opponent with the tail often beating the other fish. They also occasionally performed lateral head jerking of about $10^{\circ}$ at a frequency of two to three movements per second with the head turning towards one or both sides of the body. Sometimes, the body was tilted laterally with the sucker attached to the substratum, turning the dorsal region towards the other fish. In these displays, the mouth was sometimes opened for periods of up to 5-6 s. If the opponent did not retreat or flee, one fish often charged the other by rapid swimming and butting, or they engaged in mouth fighting. These fights were common among fishes of similar size. The opponents opened their mouths up to an angle of $170^{\circ}$, and they pushed against each other using the pectoral fins and tail movements. The longest mouth fighting observed lasted $6 \mathrm{~s}$. Agonistic interactions ended suddenly when one fish fled. Sometimes the winner chased the opponent.

The agonistic repertoire described above was common to both sexes. The frequency of intra- and intersexual interactions did not differ significantly from a random distribution (goodness of fit $\chi^{2}$ test $=4 \cdot 0$, d.f. $=2, P>0 \cdot 05$ ). The agonistic interactions seemed to be disputes over the control of shelter sites. Not only did the fish spend most of their time in shelters (mean $89 \cdot 7 \%$, s.D. $11 \cdot 7$, range $59 \cdot 3-100 \%$, for 12 fishes and $66 \mathrm{~h}$ focal observation time; Wilcoxon signed ranks test: $Z=3.059, P<0 \cdot 01$ ), but in addition most interactions occurred when one fish attempted to enter an already occupied shelter site (mean $85.8 \%, n=127$ interactions). Larger fish tended to succeed in driving away the smaller intruders and were sometimes able to dislodge smaller fish and take over their shelter [Table I(a)]. However, there was an effect of residence since larger intruders lost significantly more contests than expected by chance [Table I(b)]. Furthermore, each shelter tended to be occupied by only one fish (in 132 scanning observations in which the 
location of each fish was recorded, only in four cases were two fishes in the same shelter).

In rocky intertidal fishes of other families, both sexes may exhibit agonistic behaviour (Gibson, 1969, 1982) and, in at least some species, agonistic interactions are closely related to the control of shelter sites (Gibson, 1968; Almada et al., 1983). L. l. purpurea is a very small fish that must rely on the use of shelter sites and crypsis to avoid predators. Thus, it is likely that the agonistic behaviour observed is directly connected with the access to shelter. Whether or not this leads to a fully territorial system or to a more diffuse form of territoriality, as described by Gibson (1968) for the juveniles of Lipophrys pholis (L.), is not yet clear and needs further investigation.

This study was supported financially by Junta Nacional de Investigação Científica e Tecnológica (JNICT-PBIC/1313/MAR/92), Instituto Calouste Gulbenkian and Instituto da Juventude. We also thank Dr Teresa Avelar who reviewed the English, and Dr Ian Winfield and two anonymous referees for their valuable comments on the manuscript.

\section{References}

Almada, V., Dores, J., Pinheiro, A., Pinheiro, M. \& Santos, R. S. (1983). Contribuição para o estudo do comportamento de Coryphoblennius galerita (L.) (Pisces: Blenniidae). Memórias do Museu do Mar-Série Zoológica 2, 1-166.

Breder, C. M. \& Rosen, E. (1966). Modes of Reproduction in Fishes. New York: Natural History Press.

Briggs, J. C. (1986). Gobiesocidae. In Fishes of the North-Eastern Atlantic and the Mediterranean (Whitehead, P. J. P., Bauchot, M.-L., Hureau, J.-C., Nielsen, J. \& Tortonese, E., eds), pp. 1351-1359. Paris: UNESCO.

Briggs, J. C. (1990). Gobiesocidae. In Check-List of the Fishes of the Eastern Tropical Atlantic (Quéro, J. C., Hureau, J. C., Karrer, C., Post, A. \& Saldanha, L., eds), pp. 474-480. Lisbon: UNESCO, Societas Europaea Ichthyologorum and JNICT-Portugal.

Estabrook, C. B. \& Estabrook, G. F. (1989). ACTUS: a solution to the problem of small samples in the analysis of two-way contingency tables. Historical Methods 22, 5-8.

Fishelson, L. (1966). Contributions to the knowledge of the Red Sea. No. 36. Preliminary observations on Lepadichthys lineatus Briggs, a clingfish associated with crinoids. Bulletin Sea Fisheries Research Station, Haifa 42, 41-48.

Gibson, R. N. (1968). The agonistic behaviour of juvenile Blennius pholis L. (Teleostei). Behaviour 30, $192-217$.

Gibson, R. N. (1969). The biology and behaviour of littoral fish. Oceanography and Marine Biology Annual Review 7, 367-410.

Gibson, R. N. (1982). Recent studies on the biology of intertidal fishes. Oceanography and Marine Biology Annual Review 20, 363-414.

Martin, P. \& Bateson, P. (1993). Measuring Behaviour-An Introductory Guide, 2nd edn. Cambridge: Cambridge University Press.

Patzner, R. A., Santos, R. S., Ré, P. \& Nash, R. D. M. (1992). Littoral fishes of the Azores: an annotated checklist of fishes observed during the "Expedition Azores 1989". Arquipélago. Life and Earth Sciences 10, 101-111.

Thresher, R. E. (1984). Reproduction in Reef Fishes. Neptune City, NJ: TFH Publications. 